\title{
Модельні характеристики провідних футболістів різного ігрового амплуа
}

\section{Андрій Перцухов Віктор Шаленко}

Харківська державна академія фізичної культури, Харків, Україна

\begin{abstract}
Мета: встановити модельні характеристики спортивних можливостей і змагальної діяльності футболістів високої кваліфікації різного ігрового амплуа.

Матеріал і методи: реєстрація техніко-тактичних дій здійснювалася на прикладі ігор команд-учасниць Ліги чемпіонів УЄФА сезону 2019/2020. Всього було зареєстровано та проаналізовано 203 гри команд «Аталанта» (Бергамо, Італія), «Атлетіко» (Мадрид, Іспанія), «Баварія»(Мюнхен, Німеччина), «Барселона» (Барселона, Іспанія), «Лейпциг» (Лейпциг, Німеччина), «Ліверпуль» (Ліверпуль, Англія), «Манчестер Сіті» (Манчестер, Англія), «Олімпік» (Ліон, Франція), «Парі Сен-Жермен» (Париж, Франція). Для вирішення поставлених завдань в роботі застосовувалися такі методи дослідження: аналіз науково-методичної літератури, реєстрація техніко-тактичних дій, методи математичної статистики.
\end{abstract}

Результати: в статті представлено дані, що характеризують морфологічні особливості та особливості виконання захисних та атакувальних ТТД кращих футболістів різної ігрової спеціалізації за підсумками ігор Ліги чемпіонів УЄФА сезону 2019/2020. Розроблено моделі кращих воротарів (Ноєр М., Облак Я., Лопеш А.), захисників (Дейвіс А., Кімміх Й., Алаба Д., Упамекано Д., Анхеліньйо, Ван Дейк В.), півзахисників (Тьяго А., Горецка Л., Мюллер Т., Де Брейне К., Ауар У., Забітцер М., Маркіньйос, Гомес А.) та нападників (Гнабрі С., Левандовський Р., Мбаппе К., Неймар, Мессі Л., Стерлінг Р.).

Висновки: дані проведеного дослідження свідчать про відмінності морфологічних показників та структури змагальної діяльності кращих воротарів, захисників, півзахисників та нападників в іграх Ліги чемпіонів УЄФА сезону $2019 / 2020$.

Ключові слова: футболісти, модельні характеристики, вік, зріст, вага, теніко-тактичні дії.

\section{Вступ}

В теперішній час управління підготовкою спортсменів ґрунтується на використанні різних моделей $[5,19]$. Аналіз доступної літератури свідчить про існування декількох визначень поняття «модель». Так, В.М.Платонов [17] термін «модель» визначає як зразок, стандарт чи еталон; в більш широкому сенсі - будь-який зразок того чи іншого об'єкту, процесу або явища.

При цьому В.М.Шамардін [19] характеризує «модель», як подумки подану або матеріально реалізовану систему, що відтворює об'єкт дослідження та здатна заміщати його так, що її вивчення дає нову інформацію про цей об'єкт.

У свою чергу В.М.Костюкевич $[4,5]$ розглядає модель як певну структуру, що складається з різних показників і відображає результат спортивної або іншої діяльності людини.

Моделі, що використовуються в практиці тренувальної та змагальної діяльності, поділяються на три рівні [17]:

- узагальнені моделі, яка відображає характеристику об'єкта або процесу, виявлену на основі дослідження великої групи спортсменів певної статі, віку і кваліфікації. Моделі цього рівня носять глобальний характер і відображають найбільш загальні закономірності тренувальної та змагальної діяльності в конкретному виді спорту;
- групові моделі, які будуються на вивченні конкретної сукупності спортсменів (або команди), що відрізняються специфічними ознаками в рамках того або іншого виду спорту;

- індивідуальні моделі, які розробляються для окремих спортсменів і спираються на дані тривалого дослідження та індивідуального прогнозування структури змагальної діяльності та підготовленості окремого спортсмена.

Відомо, що управління процесом спортивної підготовки вимагає в якості необхідного елемента наявності модельних характеристик - нормативних показників, характерних для певного рівня підготовленості та спортивного результату [19, 22, 24].

Модельні характеристики розглядаються:

- як ідеальні характеристики стану спортсмена, при яких він може показати рекордні результати;

- як показники (тести), підвищення результатів в яких веде до збільшення змагальних досягнень;

- як окремі показники, що входять в склад моделі.

Для оцінки певної моделі багатьма фахівцями використовуються як модельні характеристики $[1,6]$ так і модельні показники [4, 5]. Відзначається [4, 5, 9, 10, 17], що модельні показники футболістів дозволяють ефективно управляти їх підготовкою. 
При цьому модельні показники футболістів діляться на:

1. Модельні показники спортивних можливостей. Вони включають в себе показники, що відображають морфофункціональні особливості організму. Морфофункціональні особливості футболістів оцінюються за показниками віку [11], габаритних розмірів тіла [2, 3, 7, 13, 18, 25] та функціональної підготовленості [4, 12, 20, 27, 29, 30].

2. Модельні показники спортивної майстерності. Вони ґрунтуються на рівні спеціальної фізичної, технічної й тактичної підготовленості футболістів. У практиці футболу для оцінки рівня підготовленості спортсменів найбільша увага приділяється критеріям спеціальної фізичної підготовленості [6, 19, 26].

3. Модельні показники змагальної діяльності. Вони, на думку багатьох фахівців, найбільш повно характеризують рівень підготовленості та майстерності футболістів. Контроль змагальної діяльності футболістів здійснюється у двох напрямках: контроль рухової активності [16, $21,23,28]$ та контроль ТТД [6, 8, 14, 15, 19].

Мета дослідження - встановити модельні характеристики спортивних можливостей і змагальної діяльності футболістів високої кваліфікації різного ігрового амплуа.

\section{Матеріал і методи дослідження}

Для вирішення поставлених завдань в роботі застосовувалися такі методи дослідження: аналіз науково-методичної літератури, реєстрація техніко-тактичних дій, методи математичної статистики. Реєстрація технікотактичних дій здійснювалася на прикладі ігор командучасниць Ліги чемпіонів УЄФА сезону 2019/2020. Всього було зареєстровано та проаналізовано 203 гри команд «Аталанта» (Бергамо, Італія), «Атлетіко» (Мадрид, Іспанія), «Баварія» (Мюнхен, Німеччина), «Барселона» (Барселона, Іспанія), «Лейпциг» (Лейпциг, Німеччина), «Ліверпуль» (Ліверпуль, Англія), «Манчестер Сіті» (Манчестер, Англія), «Олімпік» (Ліон, Франція), «Парі Сен-Жермен» (Париж, Франція). Так у воротарів реєструвалися наступні ТТД: відбивання м'яча, ловля м'яча, вибивання м'яча на виході, короткі та довгі передачі м'яча. У польових гравців реєструвалися такі ТТД: єдиноборства за верховий м'яч, відбирання м'яча, перехоплення м'яча, вибивання м'яча, блокування ударів, удари у ворота, обведення суперника, короткі та довгі передачі м'яча, навісні передачі м'яча в штрафну площу, передачі м'яча в розріз між захисниками та передачі м'яча під удар.

Таблиця 1

Загальна інформація про кращих футболістів Ліги чемпіонів УЄФА сезону 2019/2020

\begin{tabular}{|c|c|c|c|c|c|c|c|}
\hline Футболіст & Громадянство & Клуб & Вік & $\begin{array}{c}\text { Місяць } \\
\text { народження }\end{array}$ & 3ріст & Вага & $\begin{array}{c}\text { Провідна } \\
\text { нога }\end{array}$ \\
\hline \multicolumn{8}{|c|}{ Воротарі } \\
\hline Ноєр М. & Німеччина & «Баварія» & 33 & Березень & 193 & 92 & Права \\
\hline Облак Я. & Словенія & «Атлетіко» & 26 & Січень & 188 & 87 & Права \\
\hline Лопеш А. & Португалія & «Олімпік» & 29 & Жовтень & 184 & 81 & Ліва \\
\hline \multicolumn{8}{|c|}{ Захисники } \\
\hline Дейвіс А. & Канада & «Баварія» & 19 & Листопад & 183 & 75 & Ліва \\
\hline Кімміх Й. & Німеччина & «Баварія» & 24 & Лютий & 177 & 70 & Права \\
\hline Алаба Д. & Австрія & «Баварія» & 27 & Червень & 180 & 76 & Ліва \\
\hline Упамекано Д. & Франція & «Лейпциг» & 21 & Жовтень & 186 & 79 & Права \\
\hline Анхеліньйо & Іспанія & «Лейпциг» & 22 & Січень & 171 & 69 & Ліва \\
\hline Ван Дейк В. & Нідерланди & «Ліверпуль» & 28 & Липень & 193 & 90 & Права \\
\hline \multicolumn{8}{|c|}{ Півзахисники } \\
\hline Тьяго А. & Іспанія & «Баварія» & 28 & Квітень & 174 & 65 & Права \\
\hline Горецка Л. & Німеччина & «Баварія» & 24 & Лютий & 189 & 79 & Права \\
\hline Мюллер Т. & Німеччина & «Баварія» & 30 & Вересень & 185 & 75 & Права \\
\hline Де Брейне К. & Бельгія & $\langle\mathrm{MC}\rangle$ & 28 & Червень & 181 & 76 & Права \\
\hline Aуap У. & Франція & «Олімпік» & 21 & Червень & 175 & 70 & Права \\
\hline Забітцер М. & Австрія & «Лейпциг» & 25 & Березень & 177 & 70 & Права \\
\hline Маркіньйос & Бразилія & «ПСЖ» & 25 & Травень & 183 & 75 & Права \\
\hline Гомес А. & Аргентина & «Аталанта» & 31 & Лютий & 167 & 68 & Права \\
\hline \multicolumn{8}{|c|}{ Нападники } \\
\hline Гнабрі С. & Німеччина & «Баварія» & 24 & Липень & 176 & 72 & Права \\
\hline Левандовський Р & Польща & «Баварія» & 31 & Серпень & 185 & 81 & Права \\
\hline Мбаппе К. & Франція & $\langle\Pi C Ж »$ & 21 & Грудень & 178 & 73 & Права \\
\hline Неймар & Бразилія & $\langle\Pi$ «ПЖ» & 27 & Лютий & 175 & 68 & Права \\
\hline Мecci Л. & Аргентина & «Барселона» & 32 & Червень & 170 & 67 & Ліва \\
\hline Стерлінг Р. & Англія & $\langle\mathrm{MC} »$ & 25 & Грудень & 170 & 70 & Права \\
\hline
\end{tabular}


Таблиця 2

Середні вікові та антропометричні показники кращих футболістів Ліги чемпіонів УЄФА сезону 2019/2020 різних ігрових амплуа

\begin{tabular}{|l|c|c|c|c|c|}
\hline \multicolumn{1}{|c|}{ Показники } & $\begin{array}{c}\text { Воротарі } \\
(\mathrm{n}=3)\end{array}$ & $\begin{array}{c}\text { Захисники } \\
(\mathrm{n}=6)\end{array}$ & $\begin{array}{c}\text { Півзахисники } \\
(\mathrm{n}=8)\end{array}$ & $\begin{array}{c}\text { Нападники } \\
(\mathrm{n}=6)\end{array}$ & $\begin{array}{c}\text { Разом } \\
(\mathrm{n}=23)\end{array}$ \\
\hline Середній вік & $29,3 \pm 2,0$ & $23,5 \pm 1,4$ & $26,5 \pm 1,2$ & $26,7 \pm 1,7$ & $26,1 \pm 0,8$ \\
\hline Довжина тіла, см & $188,3 \pm 2,6$ & $181,7 \pm 3,1$ & $178,9 \pm 2,5$ & $175,7 \pm 2,3$ & $180,0 \pm 1,5$ \\
\hline Маса тіла, кг & $86,7 \pm 3,2$ & $76,5 \pm 3,1$ & $72,3 \pm 1,7$ & $71,8 \pm 2,1$ & $75,1 \pm 1,5$ \\
\hline
\end{tabular}

Для вирішення поставлених завдань в роботі застосовувалися такі методи дослідження: аналіз науково-методичної літератури, реєстрація техніко-тактичних дій, методи математичної статистики.

\section{Результати дослідження}

У таблиці 1 представлено загальні дані про кращих футболістів 2019-2020 років. 3 таблиці видно, що 323 футболістів 5 мають німецьке громадянство, 3 - французьке, по 2 - австрійське, іспанське, бразильське та аргентинське, по 1 - словенське, португальське, канадське, нідерландське, бельгійське, польське та англійське.

Найбільше представництво у символічній збірній має «Баварія» Мюнхен (9 футболістів). «РБ Лейпциг» та «ПСЖ» мають по 3 представники в списку кращих футболістів Ліги чемпіонів сезону 2019/2020. По 2 представники у даному списку мають «Олімпік» Ліон та «Манчестер Сіті». По 1 футболісту - «Атлетіко», «Ліверпуль», «Аталанта» та «Барселона».

Результати таблиці свідчать, що вік кращих футболістів сезону 2019/2020 варіювався від 19 (Дейвіс А.) до 33 років (Ноєр М.).

Аналіз антропометричних показників даної групи футболістів свідчить про те, що довжина тіла гравців варіювалася в межах від 167 (Гомес А.) до 193 см (Ноєр М.). Показники маси тіла футболістів знаходилися в межах від 65 (Тьяго А.) до 92 кг (Ноєр М.).
У таблиці 2 наведено середні морфологічні показники кращих футболістів Ліги чемпіонів сезону 2019/2020 різних ігрових амплуа.

Отримані результати частково підтверджуються раніше проведеними дослідженнями $[5,7,18]$, в яких відзначається тенденція зниження віку, довжини та маси тіла футболістів по умовній лінії розташування гравців від своїх воріт до воріт суперника.

Так, середній вік кращих воротарів сезону 2019/2020 становив $29,3 \pm 2,0$ року, захисників $-23,5 \pm 1,4$ років, півзахисників $-26,5 \pm 1,2$ року, нападників $-26,7 \pm 1,7$ року.

Також у даної групи воротарів виявилися вищими

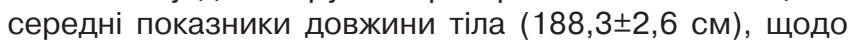
захисників $(183,7 \pm 3,1$ см), півзахисників $(178,9 \pm 2,5$ см)

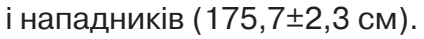

Аналогічна ситуація спостерігається і за показниками маси тіла. Так, середня вага тіла воротарів становила $86,7 \pm 3,2$ кг, захисників - 76,5 $\pm 3,1$ кг, півзахисників $72,3 \pm 1,7$ кг, нападників $-71,8 \pm 2,1$ кг.

У таблиці 3 представлено середні показники змагальної діяльності кращих воротарів Ліги чемпіонів сезону 2019/2020.

У результаті проведеного дослідження було встановлено, що кращі воротарі в іграх даного турніру на полі проводили від 93 до 124 хвилин. При цьому за гру вони виконували від 15 до 69 дотиків до м'яча.

Аналіз ТТД кращих воротарів свідчить про те, що вони в іграх Ліги чемпіонів сезону 2019/2020 здійснювали:

Таблиця 3

Показники змагальної діяльності кращих воротарів Ліги чемпіонів УЄФА сезону 2019/2020

\begin{tabular}{|l|c|c|c|}
\hline \multirow{2}{*}{\multicolumn{1}{|c|}{ Показники }} & \multicolumn{3}{|c|}{ Футболісти } \\
\cline { 2 - 4 } & 1 & 2 & 3 \\
\hline Торкання м'яча, к-ть разів & 47,7 & 30,3 & 37,8 \\
\hline Відбивання м'яча, к-ть разів & 2,5 & 2,6 & 2,5 \\
\hline Ловля м'яча, к-ть разів & 0,2 & 0,2 & 1,0 \\
\hline Вибивання м'яча на виході, к-ть разів & 0,2 & 0,4 & 0,3 \\
\hline Короткі передачі м'яча, к-ть разів & 38,8 & 22,7 & 27,5 \\
\hline Ефективність передач м'яча, \% & 86,9 & 53,5 & 68,1 \\
\hline Довгі передачі м'яча, к-ть разів & 11,2 & 18,2 & 15,2 \\
\hline Ефективність довгих передач м'яча, \% & 56,9 & 41,2 & 44,7 \\
\hline
\end{tabular}

Примітка: 1 - Ноєр М., 2 - Облак Я., 3 - Лопеш А.

Перцухов, А., Шаленко, В. (2021), «Модельні характеристики провідних футболістів різного ігроого амплуа"
Слобожанський науково-спортивний вісник, № 1(81), С. 47-58, doi:10.15391/snsv.2021-1.007 


\section{СЛОБОЖАНСЬКИЙ НАУКОВО-СПОРТИВНИЙ ВІСНИК}

\section{Торкання м'яча $(39,2)$}

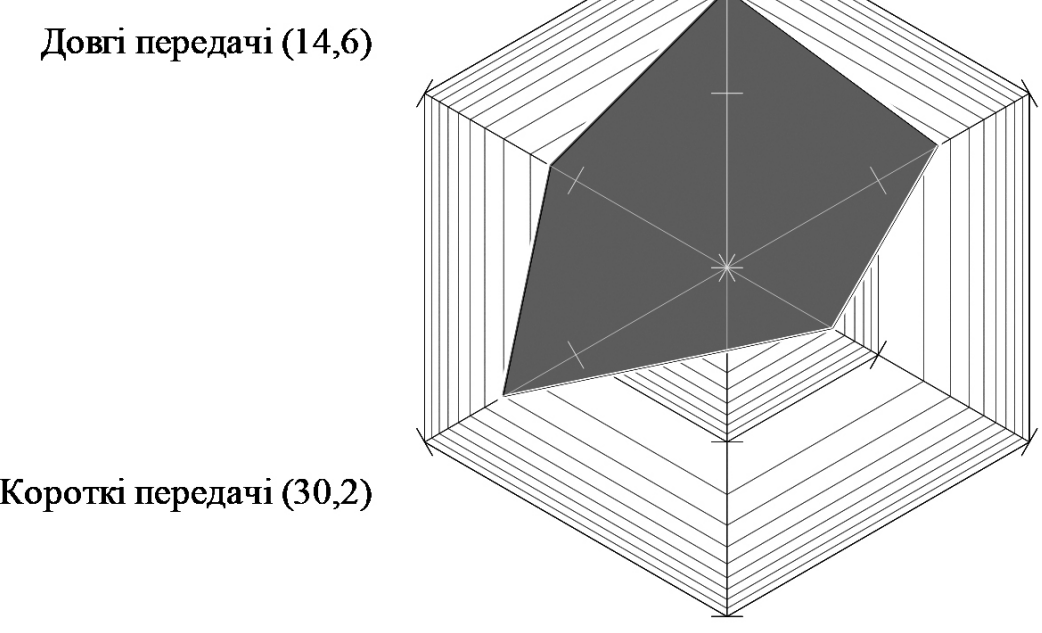

Вибивання $(0,3)$
Відбивання $(2,5)$

Ловля $(0,5)$

Рис. 1.

Модель змагальної діяльності кращих воротарів команд-учасниць Ліги чемпіонів УЄФА сезону 2019/2020

(в дужках - кількість разів)

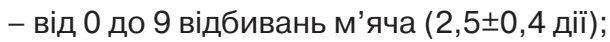

- від 0 до 3 ловіння м'яча (0,5 0,2 дії);

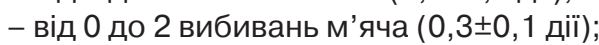

- від 10 до 62 коротких та середніх передач м'яча (30,2 $\pm 2,2$ дії);

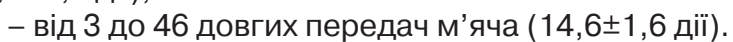

У таблиці 4 представлено середні показники змагальної діяльності кращих захисників Ліги чемпіонів сезону 2019/2020.

Встановлено, що кращі захисники в іграх Ліги чемпіонів на полі проводили від 22 до 124 хвилин. Аналіз показників змагальної діяльності футболістів даного ігрового амплуа показує, що в середньому за гру вони виконували:

- від 31 до 144 дотиків до м'яча, при середньому значенні 91,2 $\pm 2,2$ дії;

- від 0 до 7 успішних єдиноборств за верховий м'яч (1,6 $\pm 0,2$ дії);

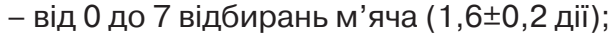

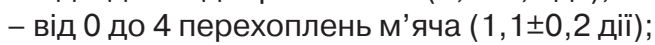

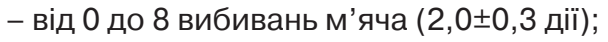

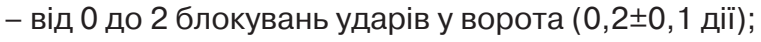

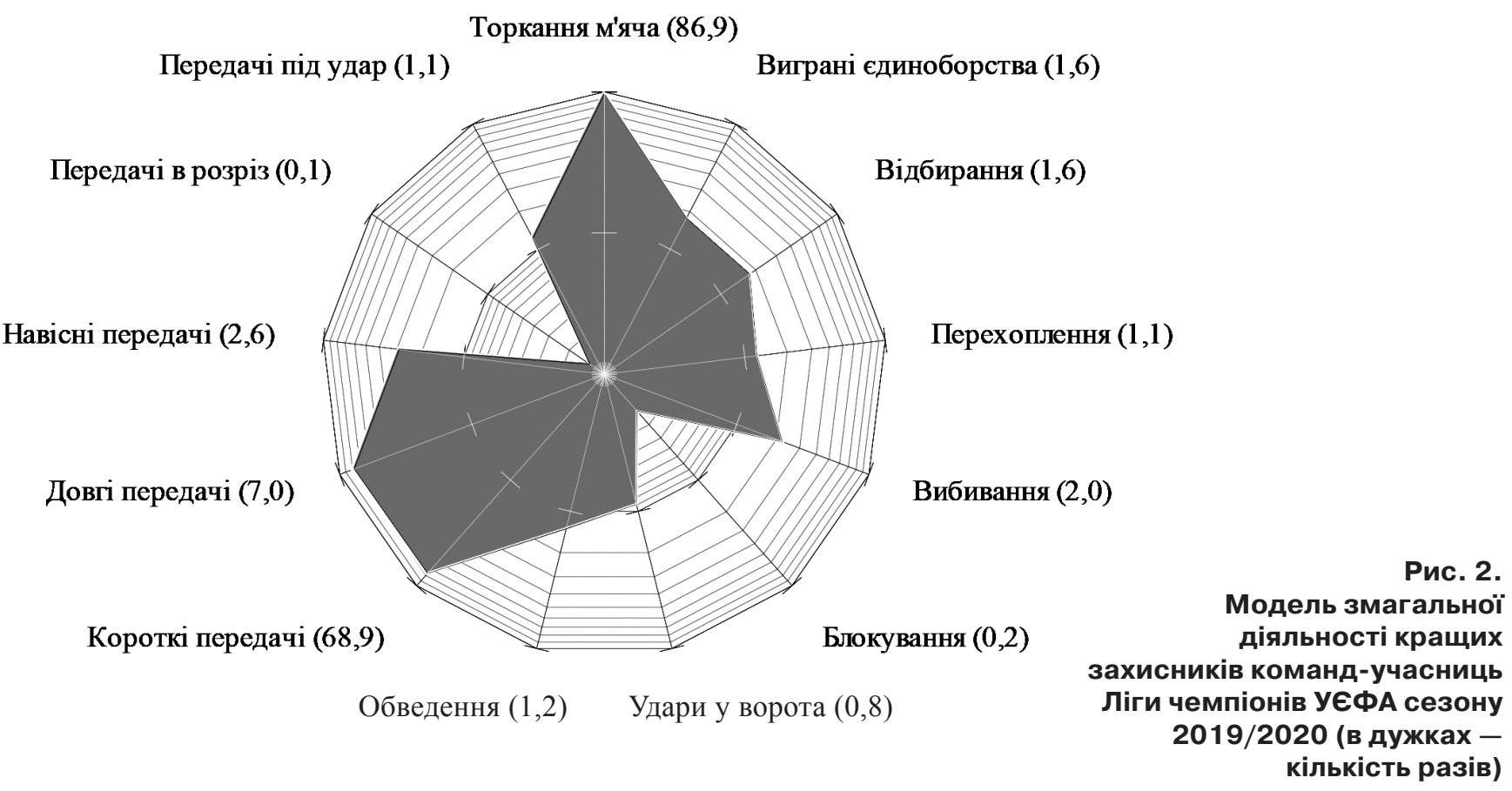


Таблиця 4

Показники змагальної діяльності кращих захисників Ліги чемпіонів УЄФА сезону 2019/2020

\begin{tabular}{|c|c|c|c|c|c|c|}
\hline \multirow{2}{*}{ Показники } & \multicolumn{6}{|c|}{ Футболісти } \\
\hline & 1 & 2 & 3 & 4 & 5 & 6 \\
\hline Торкання м’яча, к-ть разів & 83,9 & 89,5 & 80,6 & 81,6 & 73,8 & 105,8 \\
\hline Виграні єдиноборства, к-ть разів & 1,3 & 0,6 & 0,9 & 2,3 & 0,8 & 4,1 \\
\hline Відбирання м’яча, к-ть разів & 2,3 & 1,4 & 0,9 & 3,1 & 1,0 & 1,1 \\
\hline Перехоплення м’яча, к-ть разів & 1,3 & 0,9 & 0,8 & 1,5 & 1,2 & 1,1 \\
\hline Вибивання м’яча, к-ть разів & 0,9 & 0,7 & 2,0 & 3,4 & 1,4 & 4,0 \\
\hline Блокування ударів, к-ть разів & 0,0 & 0,2 & 0,3 & 0,5 & 0,0 & 0,1 \\
\hline Удари у ворота, к-ть разів & 1,0 & 0,5 & 0,6 & 1,0 & 0,8 & 1,1 \\
\hline Удари в створ воріт, к-ть разів & 0,0 & 0,4 & 0,1 & 0,4 & 0,4 & 0,1 \\
\hline Обведення суперника, к-ть разів & 3,3 & 0,6 & 0,3 & 1,9 & 1,0 & 0,1 \\
\hline Короткі передачі м'яча, к-ть разів & 56,5 & 67,7 & 73,3 & 66,4 & 51,0 & 92,0 \\
\hline Ефективність передач м’яча, \% & 88,7 & 88,0 & 89,7 & 86,7 & 80,8 & 88,7 \\
\hline Довгі передачі м’яча, к-ть разів & 2,5 & 6,6 & 6,0 & 7,6 & 3,8 & 14,6 \\
\hline Ефективність довгих передач м'яча, \% & 68,6 & 69,7 & 47,7 & 59,4 & 22,0 & 64,1 \\
\hline $\begin{array}{l}\text { Навісні передачі } \\
\text { площу, к-ть разів }\end{array}$ & 2,3 & 6,7 & 0,5 & 0,1 & 5,2 & 0,0 \\
\hline $\begin{array}{l}\text { Ефективність передач } \\
\text { штрафну площу, \% }\end{array}$ & 15,4 & 19,4 & 83,4 & 0,0 & 21,9 & - \\
\hline 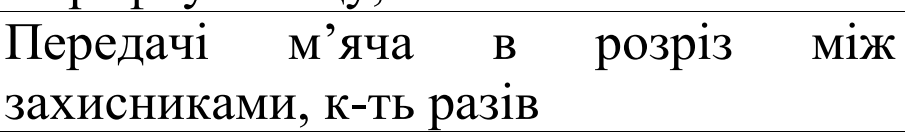 & 0,1 & 0,3 & 0,0 & 0,0 & 0,0 & 0,0 \\
\hline $\begin{array}{l}\text { Ефективність передач м'яча в розріз } \\
\text { між захисниками, \% }\end{array}$ & 100,0 & 33,3 & - & . & - & 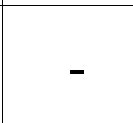 \\
\hline Передачі м’яча під удар, к-ть разів & 1,1 & 2,5 & 0,5 & 0,1 & 1,2 & 0,5 \\
\hline
\end{tabular}

Примітка: 1 - Дейвіс А., 2 - Кімміх Й., 3 - Алаба Д., 4 - Упамекано Д., 5 - Анхеліньйо, 6 - Ван Дейк В.

- від 0 до 4 ударів у ворота $(0,8 \pm 0,1$ дії);

- від 0 до 8 обведень суперника ( $1,2 \pm 0,3$ дії);

- від 25 до 126 коротких та середніх передач м'яча

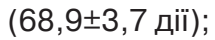

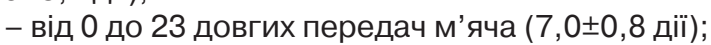

- від 0 до 15 навісних передач м'яча в штрафну площу $(2,6 \pm 0,5$ дії);

- від 0 до 1 передачі м'яча в розріз між захисниками

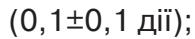

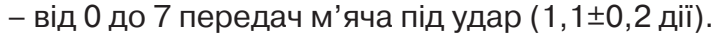

у табл. 5 наведено середні показники змагальної діяльності кращих півзахисників Ліги чемпіонів сезону $2019 / 2020$.
Аналіз показників змагальної діяльності півзахисників свідчить про те, що кращі представники даного амплуа в іграх Ліги чемпіонів УЄФА сезону 2019/2020 на полі проводили від 4 до 101 хвилини, при середньому значенні по групі 85,2 2 2,6 хвилини.

Встановлено, що вісім півзахисників в іграх даного турніру виконували:

- від 3 до 132 дотиків до м'яча, при середньому значенні 67,3 $\pm 3,0$ ТТД;

- від 0 до 10 успішних єдиноборств за верховий м'яч (1,1 $\pm 0,2$ ТТД);

- від 0 до 8 відбирань м'яча (1,7士0,2 ТТД);

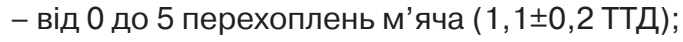


Таблиця 5

Показники змагальної діяльності кращих півзахисників Ліги чемпіонів УЄФА сезону 2019/2020

\begin{tabular}{|c|c|c|c|c|c|c|c|c|}
\hline \multirow{2}{*}{ Показники } & \multicolumn{8}{|c|}{ Футболісти } \\
\hline & 1 & 2 & 3 & 4 & 5 & 6 & 7 & 8 \\
\hline Торкання м’яча, к-ть разів & 96,2 & 46,9 & 43,2 & 64,9 & 63,5 & 78,4 & 77,8 & 59,0 \\
\hline Виграні єдиноборства, к-ть разів & 1,3 & 0,9 & 1,0 & 0,7 & 0,5 & 0,7 & 3,0 & 0,0 \\
\hline Відбирання м’яча, к-ть разів & 3,4 & 1,9 & 1,5 & 1,1 & 1,8 & 0,7 & 2,0 & 0,7 \\
\hline Перехоплення м’яча, к-ть разів & 2,3 & 1,3 & 0,5 & 0,9 & 0,6 & 1,0 & 1,5 & 0,7 \\
\hline Вибивання м’яча, к-ть разів & 0,4 & 0,4 & 0,5 & 0,7 & 0,1 & 0,6 & 2,5 & 0,2 \\
\hline Блокування ударів, к-ть разів & 0,0 & 0,3 & 0,0 & 0,0 & 0,3 & 0,1 & 1,1 & 0,1 \\
\hline Удари у ворота, к-ть разів & 0,7 & 2,4 & 2,0 & 2,3 & 1,1 & 2,4 & 0,6 & 1,8 \\
\hline Удари в створ воріт, к-ть разів & 0,1 & 0,4 & 0,9 & 0,9 & 0,6 & 1,0 & 0,3 & 0,8 \\
\hline Обведення суперника, к-ть разів & 1,3 & 0,4 & 0,5 & 2,0 & 4,4 & 0,6 & 0,1 & 1,8 \\
\hline Короткі передачі м'яча, к-ть разів & 83,2 & 35,4 & 30,2 & 41,9 & 37,6 & 58,7 & 65,1 & 38,2 \\
\hline Ефективність передач м’яча, \% & 91,0 & 87,8 & 79,3 & 76,3 & 78,7 & 82,8 & 85,3 & 84,9 \\
\hline Довгі передачі м’яча, к-ть разів & 11,0 & 3,1 & 1,4 & 3,1 & 2,5 & 4,6 & 5,2 & 2,4 \\
\hline $\begin{array}{l}\text { Ефективність довгих передач } \\
\text { м'яча, \% }\end{array}$ & 78,1 & 81,0 & 64,3 & 53,8 & 46,9 & 52,6 & 42,0 & 48,8 \\
\hline $\begin{array}{l}\text { Навісні передачі м'яча в штрафну } \\
\text { площу, к-ть разів }\end{array}$ & 0,0 & 0,3 & 2,2 & 8,7 & 1,3 & 4,9 & 0,1 & 5,4 \\
\hline $\begin{array}{l}\text { Ефективність передач м'яча } \\
\text { штрафну площу, \% }\end{array}$ & - & 50,0 & 22,3 & 26,2 & 25,0 & 30,6 & 100,0 & 24,0 \\
\hline $\begin{array}{l}\text { Передачі м'яча в розріз між } \\
\text { захисниками, к-ть разів }\end{array}$ & 0,4 & 0,3 & 0,3 & 1,1 & 0,3 & 0,0 & 0,2 & 0,7 \\
\hline $\begin{array}{l}\text { Ефективність передач м'яча в } \\
\text { розріз між захисниками, \% }\end{array}$ & 75,0 & 50,0 & 25,0 & 40,0 & 0,0 & - & 50,0 & 33,3 \\
\hline Передачі м'яча під удар, к-ть разів & 1,5 & 0,3 & 2,5 & 3,9 & 1,4 & 1,2 & 0,2 & 2,0 \\
\hline
\end{tabular}

Примітка: 1 - Тьяго А., 2 - Горецка Л., 3 - Мюллер Т., 4 - Де Брейне К., 5 - Ауар У., 6 - Забітцер М., 7 - Маркіньйос, 8 - Гомес А.

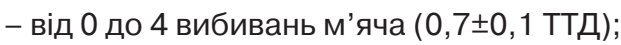

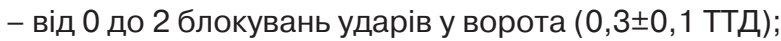

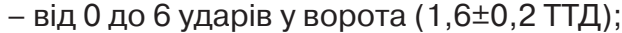

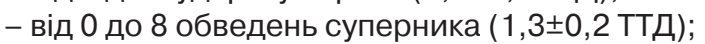

- від 2 до 117 коротких та середніх передач м'яча $(50,2 \pm 2,8$ ТТД):

- від 0 до 15 довгих передач м'яча (4,3ะ0,5 ТТД);

- від 0 до 17 навісних передач м'яча в штрафну площу $(2,7 \pm 0,5$ ТТД);

- від 0 до 3 передач м'яча в розріз між захисниками $(0,4 \pm 0,1$ ТТД);

- від 0 до 9 передач м'яча під удар (1,6士0,2 ТТД).

у таблиці 6 представлено середні показники змагальної діяльності кращих нападників Ліги чемпіонів УЄФА сезону 2019/2020.
У результаті проведеного дослідження було встановлено, що кращі нападники в іграх даного турніру на полі проводили від 20 до 101 хвилини, при середньому

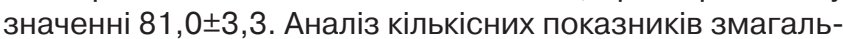
ної діяльності свідчить про те, що гравці лінії нападу в іграх Ліги чемпіонів сезону 2019/2020 здійснювали:

- від 7 до 113 дотиків до м'яча (53,6ะ3,3 ТТД);

- від 0 до 4 успішних єдиноборств за верховий м'яч (0,8 $\pm 0,2$ ТТД);

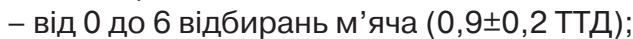

- від 0 до 2 перехоплень м'яча (0,3 0,1 ТТД);

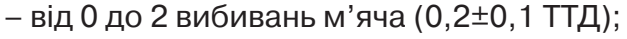

- від 0 до 1 блокувань ударів у ворота $(0,1 \pm 0,1$ ТТД);

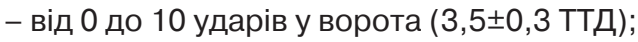

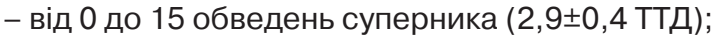




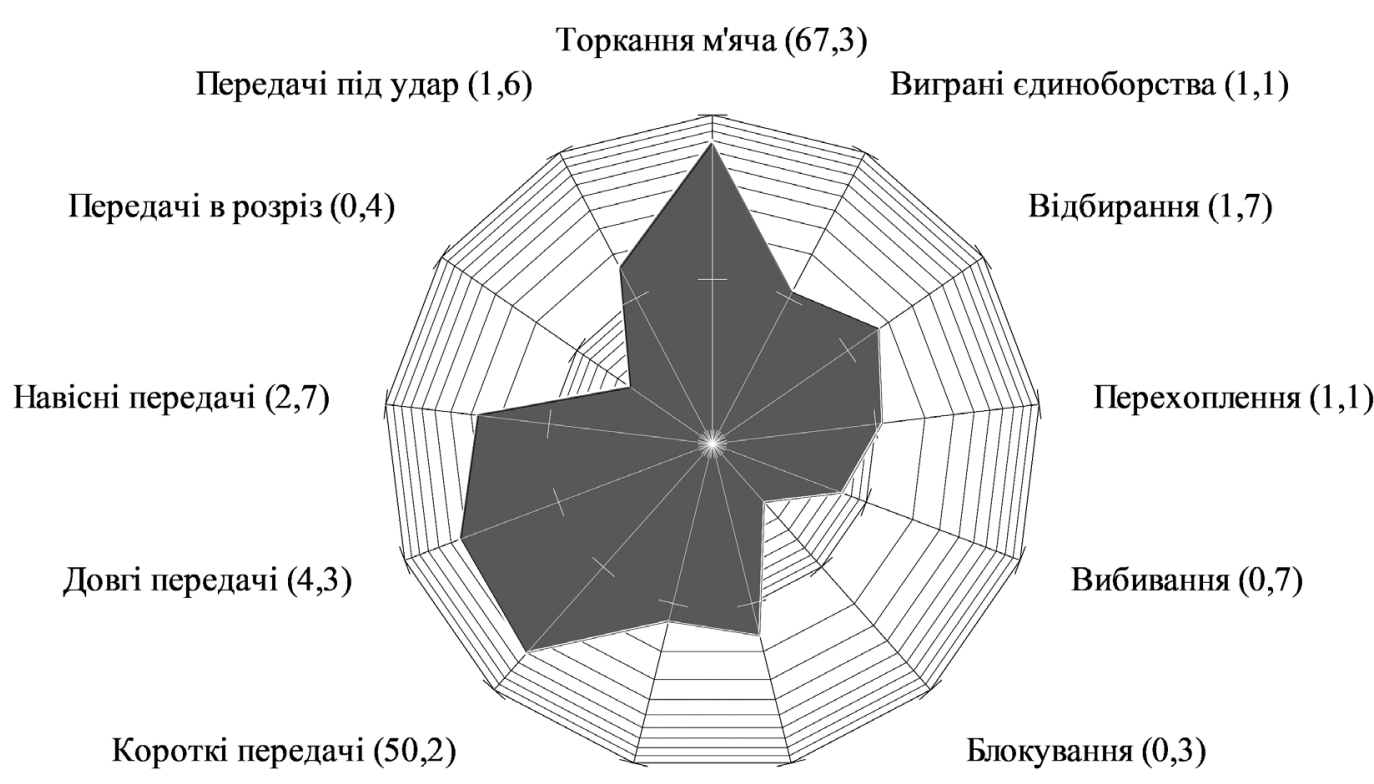

Короткі передачі $(50,2)$

Обведення $(1,3) \quad$ Удари у ворота $(1,6)$
Рис. 3. Модель змагальної діяльності кращих півзахисників команд-учасниць Ліги чемпіонів УЄФА сезону 2019/2020 (в дужках кількість разів)

Таблиця 6

Показники змагальної діяльності кращих нападників Ліги чемпіонів УЄФА сезону 2019/2020

\begin{tabular}{|l|c|c|c|c|c|c|}
\hline \multirow{2}{*}{ Показники } & \multicolumn{7}{|c|}{ Футболісти } \\
\cline { 2 - 8 } & 1 & 2 & 3 & 4 & 5 & 6 \\
\hline Торкання м'яча, к-ть разів & 53,5 & 42,6 & 39,4 & 82,0 & 76,1 & 41,4 \\
\hline Виграні єдиноборства, к-ть разів & 0,5 & 2,8 & 0,3 & 0,3 & 0,4 & 0,2 \\
\hline Відбирання м'яча, к-ть разів & 2,1 & 1,0 & 0,4 & 1,0 & 0,1 & 0,7 \\
\hline Перехоплення м’яча, к-ть разів & 0,5 & 0,2 & 0,1 & 0,3 & 0,3 & 0,7 \\
\hline Вибивання м'яча, к-ть разів & 0,2 & 0,8 & 0,0 & 0,0 & 0,0 & 0,2 \\
\hline Блокування ударів, к-ть разів & 0,0 & 0,0 & 0,0 & 0,0 & 0,0 & 0,1 \\
\hline Удари у ворота, к-ть разів & 2,7 & 5,2 & 3,0 & 3,4 & 4,0 & 2,7 \\
\hline Удари в створ воріт, к-ть разів & 1,6 & 3,3 & 1,8 & 1,0 & 1,9 & 1,4 \\
\hline Обведення суперника, к-ть разів & 1,2 & 1,2 & 1,5 & 6,1 & 7,7 & 2,0 \\
\hline Короткі передачі м’яча, к-ть разів & 36,3 & 24,8 & 24,4 & 46,6 & 49,1 & 23,9 \\
\hline Ефективність передач м'яча, \% & 84,4 & 77,5 & 84,8 & 73,6 & 81,5 & 77,6 \\
\hline Довгі передачі м’яча, к-ть разів & 1,1 & 0,6 & 0,8 & 3,0 & 2,4 & 0,3 \\
\hline Ефективність довгих передач м'яча, \% & 61,1 & 90,0 & 66,7 & 20,5 & 63,9 & 25,0 \\
\hline $\begin{array}{l}\text { Навісні передачі м'яча в штрафну } \\
\text { площу, к-ть разів }\end{array}$ & 2,5 & 0,6 & 1,3 & 3,4 & 2,0 & 0,9 \\
\hline $\begin{array}{l}\text { Ефективність передач м'яча } \\
\text { штрафну площу, \% }\end{array}$ & 14,6 & 30,0 & 8,3 & 14,3 & 20,0 & 16,7 \\
\hline $\begin{array}{l}\text { Передачі м’яча в розріз між } \\
\text { захисниками, к-ть разів }\end{array}$ & 0,2 & 0,2 & 0,3 & 2,1 & 1,6 & 0,3 \\
\hline $\begin{array}{l}\text { Ефективність передач м’яча в розріз } \\
\text { між захисниками, \% }\end{array}$ & 100,0 & 50,0 & 100,0 & 20,0 & 18,7 & 33,3 \\
\hline Передачі м’яча під удар, к-ть разів & 1,2 & 2,1 & 1,3 & 2,3 & 2,3 & 1,8 \\
\hline
\end{tabular}

Примітка: 1 - Гнабрі С., 2 - Левандовський Р., 3 - Мбаппе К., 4 - Неймар, 5 - Мессі Л., 6 - Стерлінг Р. 


\section{Торкання м'яча $(42,6)$}

Передачі під удар $(2,1) \quad$ Виграні сдиноборства $(2,8)$

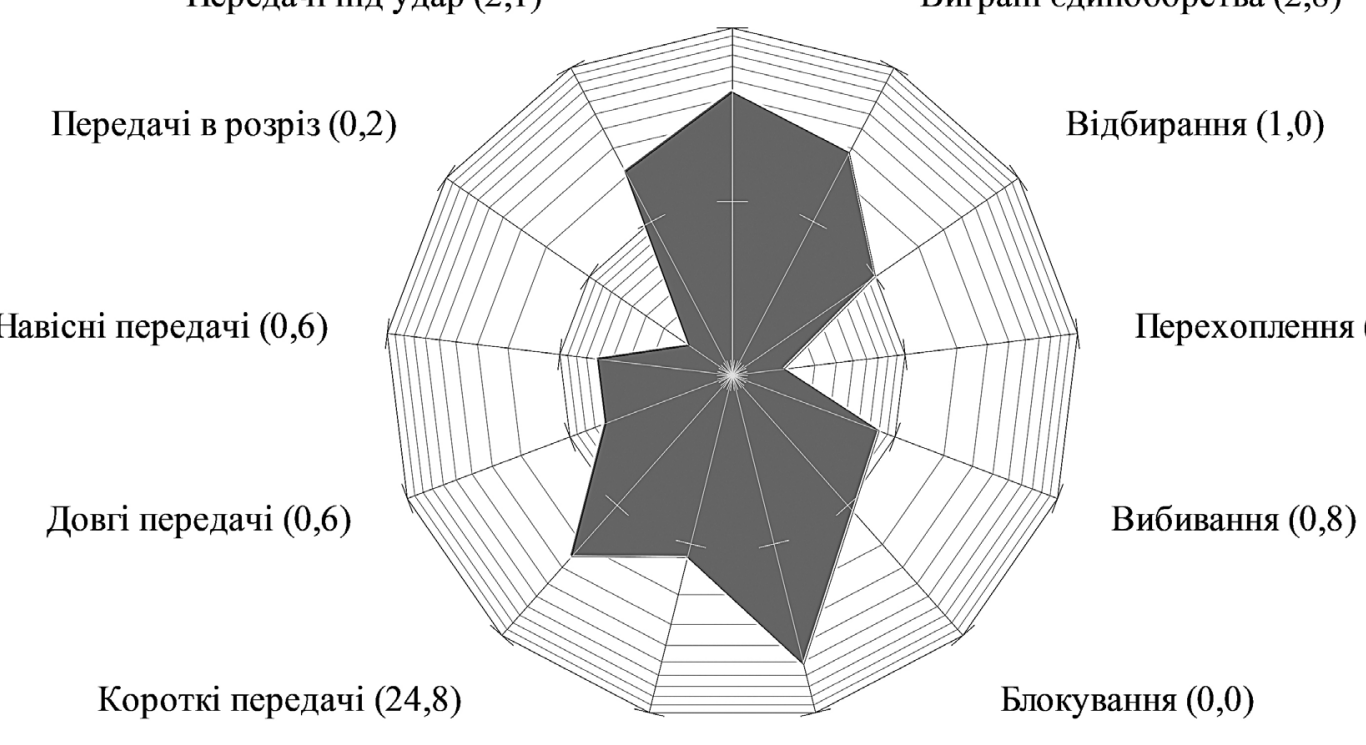

Обведення $(1,2) \quad$ Удари у ворота $(5,2)$
Рис. 4.

Модель змагальної діяльності кращих нападників команд-учасниць Ліги чемпіонів УЄФА сезону 2019/2020 (в дужках кількість разів)
- від 2 до 70 коротких та середніх передач м'яча (32,8 $\pm 2,2$ ТТД);

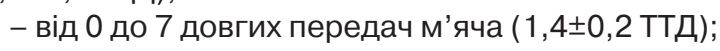

- від 0 до 7 навісних передач м'яча в штрафну площу (1,8 $\pm 0,2$ ТТД);

- від 0 до 5 передач м'яча в розріз між захисниками $(0,7 \pm 0,2$ ТТД);

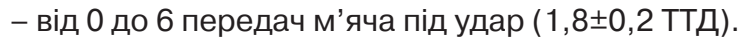

У таблиці 7 наведено середні показники змагальної діяльності кращих футболістів Ліги чемпіонів УЄФА сезону 2019/2020 різної ігрової спеціалізації.

У результаті порівняльного аналізу кількісних показників ТТД кращих футболістів Ліги чемпіонів УЄФА сезону 2019/2020 різних амплуа було встановлено, що захисники суттєво перевершують півзахисників за показниками дотиків до м'яча ( $t=4,11 ; p<0,001)$, вибивань м'яча ( $t=4,11 ; p<0,001)$, коротких $(t=4,03 ; p<0,001)$ та довгих (t=2,86; $p<0,01)$ передач м'яча. У свою чергу півзахисники в середньому за гру виконували значно більше ударів у ворота $(t=3,58 ; p<0,001)$ та передач м'яча в розріз між захисниками $(t=2,12 ; p<0,05)$.

Ще більш істотні відмінності виявлено нами в показниках ТТД кращих захисників та нападників Ліги чемпіонів УЄФА сезону 2019/2020. Так, захисники в середньому за гру здійснювали суттєво більше дотиків до м'яча $(\mathrm{t}=6,72$; $\mathrm{p}<0,001)$, вигранихєдиноборств за верховий м'яч ( $\mathrm{t}=2,83$; $p<0,01)$, відбирань м'яча $(t=2,47 ; p<0,05)$, перехоплень м'яча $(t=3,58 ; p<0,001)$, вибивань м'яча $(t=5,69 ; p<0,001)$, коротких (t=8,39; $\mathrm{p}<0,001)$ та довгих $(t=6,79 ; p<0,001)$ передач м'яча. Натомість гравці лінії нападу значно перевершували захисників за показниками ударів у ворота $(t=8,54 ; p<0,001)$, обведень суперника $(t=3,40 ; p<0,001)$, передач м'яча в розріз між захисниками $(t=2,68 ; p<0,01)$ та передач м'яча під удар ( $t=2,47 ; p<0,05)$.

Порівнюючи кількісні показники ТТД кращих півзахисників та нападників в іграх Ліги чемпіонів УЄФА, встановлено, що півзахисники в середньому за гру виконува- ли достовірно більше дотиків до м'яча ( $t=3,07 ; p<0,01)$, відбирань м'яча ( $t=2,83 ; p<0,01)$, перехоплень м'яча $(t=3,58 ; p<0,001)$, вибивань м'яча $(t=3,54 ; p<0,001)$, коротких $(t=4,89 ; p<0,001)$ та довгих $(t=5,39 ; p<0,001)$ передач м'яча. При цьому нападники перевершували півзахисників за показниками ударів у ворота ( $\mathrm{t}=5,27$; $\mathrm{p}<0,001)$ та обведень суперника (t=3,58; $\mathrm{p}<0,001)$.

\section{Висновки / Дискусія}

Дані проведеного дослідження свідчать про відмінності морфологічних показників та структури змагальної діяльності кращих футболістів різного амплуа в іграх Ліги чемпіонів УЄФА сезону 2019/2020.

Підтверджено дані (Костюкевич В.М., 2006) щодо модельних показників спортивних можливостей висококваліфікованих футболістів різного ігрового амплуа. Доповнено і розширено дані (Голомазов С.В., Чирва Б.Г., 2003, Мартиросов Е., Балучи Р., 2006, Шаленко В.В., Перцухов А.А., 2016, Перевозник В.І., Перцухов А.А., 2018) щодо вікових та антропометричних показників футболістів високої кваліфікації. Отримані дані дозволяють стверджувати, що пік спортивної майстерності у футболі знаходиться у віковому діапазоні від 25 до 29 років. Встановлено тенденцію зниження віку, довжини та маси тіла футболістів по умовній лінії розташування гравців від своїх воріт до воріт суперника. В результаті проведеного дослідження встановлено, що кращі футболісти Ліги чемпіонів УЄФА різного амплуа мають характерні габаритні розміри тіла та ряд їх відмінностей.

Результати проведеного дослідження підтвердили інформацію щодо кількісних та якісних показників ТТД польових гравців різної кваліфікації. Доповнено та розширено дані щодо особливостей виконання ТТД воротарями різного рівня. Так, в даному дослідженні відзначається вплив ігрової спеціалізації футболістів на структуру змагальної діяльності окремих футболістів і 


\section{СЛОБОЖАНСЬКИЙ НАУКОВО-СПОРТИВНИЙ ВІСНИК}

Таблиця 7

Показники змагальної діяльності кращих футболістів Ліги чемпіонів УЄФА сезону 2019/2020 різного амплуа

\begin{tabular}{|c|c|c|c|}
\hline Показники & Захисники & Півзахисники & Нападники \\
\hline Торкання м’яча, к-ть разів & $86,9 \pm 3,7$ & $67,3 \pm 3,0$ & $53,6 \pm 3,3$ \\
\hline Виграні єдиноборства, к-ть разів & $1,6 \pm 0,2$ & $1,1 \pm 0,2$ & $0,8 \pm 0,2$ \\
\hline Відбирання м'яча, к-ть разів & $1,6 \pm 0,2$ & $1,7 \pm 0,2$ & $0,9 \pm 0,2$ \\
\hline Перехоплення м’яча, к-ть разів & $1,1 \pm 0,2$ & $1,1 \pm 0,2$ & $0,3 \pm 0,1$ \\
\hline Вибивання м’яча, к-ть разів & $2,0 \pm 0,3$ & $0,7 \pm 0,1$ & $0,2 \pm 0,1$ \\
\hline Блокування ударів, к-ть разів & $0,2 \pm 0,1$ & $0,3 \pm 0,1$ & $0,1 \pm 0,1$ \\
\hline Удари у ворота, к-ть разів & $0,8 \pm 0,1$ & $1,6 \pm 0,2$ & $3,5 \pm 0,3$ \\
\hline Удари в створ воріт, к-ть разів & $0,2 \pm 0,1$ & $0,6 \pm 0,1$ & $1,9 \pm 0,2$ \\
\hline Обведення суперника, к-ть разів & $1,2 \pm 0,3$ & $1,3 \pm 0,2$ & $2,9 \pm 0,4$ \\
\hline Короткі передачі м'яча, к-ть разів & $68,9 \pm 3,7$ & $50,2 \pm 2,8$ & $32,8 \pm 2,2$ \\
\hline Ефективність передач м’яча, \% & $87,5 \pm 0,7$ & $83,5 \pm 1,0$ & $80,3 \pm 1,3$ \\
\hline Довгі передачі м’яча, к-ть разів & $7,0 \pm 0,8$ & $4,3 \pm 0,5$ & $1,4 \pm 0,2$ \\
\hline Ефективність довгих передач м'яча, \% & $57,8 \pm 4,2$ & $58,0 \pm 4,0$ & $57,3 \pm 6,7$ \\
\hline $\begin{array}{l}\text { Навісні передачі м'яча в штрафну } \\
\text { площу, к-ть разів }\end{array}$ & $2,6 \pm 0,5$ & $2,7 \pm 0,5$ & $1,8 \pm 0,2$ \\
\hline $\begin{array}{l}\text { Ефективність передач } \\
\text { штрафну площу, \% }\end{array}$ & $22,7 \pm 4,9$ & $28,6 \pm 5,4$ & $16,3 \pm 4,4$ \\
\hline $\begin{array}{lccc}\text { Передачі м'яча } & \text { в } \\
\text { захисниками, к-ть разів } & \text { розріз } & \text { між } \\
\end{array}$ & $0,1 \pm 0,1$ & $0,4 \pm 0,1$ & $0,7 \pm 0,2$ \\
\hline $\begin{array}{l}\text { Ефективність передач м'яча в розріз } \\
\text { між захисниками, \% }\end{array}$ & $50,0 \pm 28,9$ & $42,1 \pm 10,5$ & $40,6 \pm 9,8$ \\
\hline Передачі м’яча під удар,к-ть разів & $1,1 \pm 0,2$ & $1,6 \pm 0,2$ & $1,8 \pm 0,2$ \\
\hline
\end{tabular}

команди в цілому. Вперше розроблено моделі змагальної діяльності кращих футболістів різного амплуа в іграх Ліги чемпіонів УЄФА сезону 2019/2020.

Основні положення та висновки даного дослідження можуть враховуватися при формуванні клубних та збірних команд різного рівня та при побудові техніко-тактичних вправ для футболістів різної ігрової спеціалізації.

Перспективи подальших досліджень. Подальші дослідження будуть присвячені встановленню особливостей виконання командних ТТД футболістами високої кваліфікації.

Конфлікт інтересів. Автори заявляють, що відсутній конфлікт інтересів, який може сприйматись таким, що може завдати шкоди неупередженості статті.

Джерела фінансування. Ця стаття не отримала фінансової підтримки від державної, громадської або комерційної організації.

\section{Список посилань}

1. Голомазов С., Чирва Б. (2000), «Модельные характеристики игры в штрафной площади», Теория и практика футбола, №2 (6), C. 2-4.

2. Голомазов С., Чирва Б. (2003), «Морфологические признаки вратарей высокой квалификации», Теория и практика футбола, №2 (18), С. 25-28.

3. Губа В., Кузьменко Ю., Строева И., Чернова В. (2001), «Морфологическая характеристика футболистов 17-18 лет», Теория и практика футбола, №3 (11), С. 17-19.

4. Костюкевич В. М. (2006), «Модельні показники функціональної підготовленості футболістів», Збірник наукових праць 3 галузі фізичної культури і спорту, №10, С. 78. 
5. Костюкевич В. М. (2006), Управление тренировочным процессом футболистов в годичном цикле подготовки, Винница: Планер, 683 с.

6. Максименко І. Г., Костюнін А. В. (2007), «Аналіз показників змагальної діяльності футболістів збірної команди України на чемпіонаті світу 2006», Слобожанський науково-спортивний вісник, № 11, С. 47-54.

7. Мартиросов Э., Балучи Р. (2006), «Морфологические особенности футболистов высокой квалификации разных амплуа», Футбол-Профи, №2, С. 60-65.

8. Мулик В. В., Перевозник В. І., Перцухов А. А. (2015), «Характеристика епізодів гри в штрафному майданчику команди суперника», Слобожанський науково-спортивний вісник, №3 (47), С. 75-79.

9. Перевозник В. И., Перцухов А. А. (2016), «Модельные показатели подготовленности футболистов высокой квалификации», Проблемы и перспективы развития спортивных игр и единоборств в высших учебных заведениях, С. 34-39.

10. Перевозник В. И., Перцухов А. А. (2017), «Модельные показатели соревновательной деятельности футболистов высокой квалификации", Проблемы и перспективы развития спортивных игр и единоборств в высших учебных заведениях, С. 41-45.

11. Перевозник В. И., Перцухов А. А. (2018), «Возрастные и антропометрические показатели футболистов высокой квалификации», Слобожанський науково-спортивний вісник, №6 (68). С. 65-69.

12. Перевозник В. И., Перцухов А. А. (2018), «Функциональная подготовленность футболистов высокой квалификации», Проблемы и перспективы развитие спортивных игр и единоборств в высших учебных заведениях, С. 60-65.

13. Перцухов А. А. (2011), «Взаимосвязь показателей габаритных размеров тела и функциональной подготовленности футболистов 17-19 лет», Физическое воспитание студентов, №4, С. 64-66.

14. Перцухов А. А. (2017), «Особенности выполнения передач мяча футболистами команды «Лестер Сити» в играх чемпионата Англии 2015-2016 гг.», Слобожанський науково-спортивний вісник, №3 (59), С. 101-105.

15. Перцухов А. А. (2018), “Характеристика результативных ударов в ворота в играх команд высокой квалификации», Спортивные игры, №2 (8), С. 54-60.

16. Перцухов А. А., Перевозник В. И. (2019), «Двигательная активность футболистов высокой квалификации в условиях соревновательной деятельности», Спортивные игры, №1 (11), С. 32-39.

17. Платонов В. Н. (2004), Система подготовки спортсменов в олимпийском спорте. Общая теория и ее практическое приложение, Киев: Олимпийская литература, 808 с.

18. Шаленко В. В., Перцухов А. А. (2016), «Антропометрические показатели футболистов высокой квалификации», Проблемы и перспективы развития спортивных игр и единоборств в высших учебных заведениях, С. 53-56.

19. Шамардин В. Н. (2002), Моделирование подготовленности квалифицированных футболистов, Днепропетровск: Пороги, 200 с.

20. Bangsbo J. (1993), «The physiology of soccer - with special reference to intense intermittent exercise», HO + Storm, 155 p.

21. Bangsbo J. (1994), «Energy demands in competitive soccer», J. Sports Sci, №12, S. 5-12.

22. Bangsbo J. (1998), «The physiological profile of soccer players», Sports Exercise and Injury, №4, P. 144-150.

23. Bangsbo J., Norregaard L., Thorsoe F. (1991), «Activity profile of competition soccer», J. Sports Sci, №16 (2), P. 6-110.

24. Brewel J., Davis J.A. (1992), «A physiological comparison of English professional and semi-professional soccer players», J. Sports Sci, №10, P. 7-146.

25. Broad E. M., Burke L. M., Cox G. R., Heeley P, Riley M. (1996), «Body weight changes and voluntary fluid intakes during training and competition sessions in team sport», Int J Sport Nutr, №6 (3), P. 20-307.

26. Casajus J. A. (2001), "Seasonal variation in fitness variables in professional soccer players», J. Sports Med. Phys. Fitness, №41 (4), P. 9-463.

27. Davies J. A., Brewer J., Atkin D. (1992), «Preseasonal physiological characteristics of English first and second division soccer players», Journal of Sports Sciences, №10, P. 541-547.

28. Dupont G., Akakpo K., Berthoin S. (2004), «The effect of in-season, high-intensity interval training in soccer players», J Strength Cond Res, №18 (3), P. 9-584.

29. Pertsukhov A., Perevoznick V., Shalenko V., Zhurid S., Khudyakova V., Koval S. (2018), «Functional preparedness of football players with different qualifications", The Journal of Physical Education and Sport is now a registered trademark (all rights reserved), №104, PP. 710-714.

30. Heller J., Prochazka L., Bunc V. (1992), «Functional capacity in top league football players during the competitive season», J. Sports Sci, №10, 150 p.

Стаття надійшла до редакції: 22.01.2021 р.

Опубліковано: 22.02.2021 р.

Аннотация. Андрей Перцухов, Виктор Шаленко. Модельные характеристики ведущих футболистов разного игрового амплуа. Цель: установить модельные характеристики спортивных возможностей и соревновательной деятельности футболистов высокой квалификации разного игрового амплуа. Материал и методы: регистрация технико-тактических действий осуществлялась на примере игр команд-участниц Лиги чемпионов УЕФА сезона 2019/2020. Всего было зарегистрировано и проанализированы 203 игры команд «Аталанта» (Бергамо, Италия), «Атлетико» (Мадрид, Испания), «Бавария» (Мюнхен, Германия), «Барселона»(Барселона, Испания), «Лейпциг»(Лейпциг, Германия), «Ливерпуль» (Ливерпуль, Англия), «Манчестер Сити» (Манчестер, Англия), «Олимпик» (Лион, Франция), «Пари Сен-Жермен» (Париж, Франция). Для решения поставленных задач в работе применялись следующие методы исследования: анализ научно-методической литературы, регистрация технико-тактических действий, методы математической статистики. Результаты: в статье представлены данные, характеризующие морфологические особенности и особенности выполнения оборонительных и атакующих ТТД лучших футболистов разной игровой специализации по итогам игр Лиги чемпионов УЕФА сезона 2019/2020. Разработаны модели лучших вратарей (Нойер М., Облак Я., Лопеш А.), защитников (Дейвис А., Киммих Й., Алаба Д., Упамекано Д., Анхелиньо, Ван Дейк В.), полузащитников (Тьяго А., Горецка Л., Мюллер Т., Де Брейне К., Ауар В., Забитцер М., Маркиньос, Гомес А.) и нападающих (Гнабри С., Левандовский Р., Мбаппе К., Неймар, Месси Л., Стерлинг Р .). Выводы: данные проведенного исследования свидетельствуют о различиях морфологических показателей и структуры соревновательной деятельности лучших вратарей, защитников, полузащитников и нападающих в играх Лиги чемпионов УЕФА сезона 2019/2020.

Ключевые слова: футболисты, модельные характеристики, возраст, рост, вес, технико-тактические действия.

Перцухов, А., Шаленко, В. (2021), «Модельні характеристики провідних футболістів різного ігроого амплуа» doi:10.15391/snsv.2021-1.007 


\section{СЛОБОЖАНСЬКИЙ НАУКОВО-СПОРТИВНИЙ ВІСНИК}

Abstract. Andrey Pertsukhov, Victor Shalenko. Model characteristics of leading football players of different positions. Purpose: to establish the model characteristics of sports opportunities and competitive activities of highly qualified football players of different positions. Material and methods: registration of technical and tactical actions was carried out on the example of games of participating teams in the 2019/2020 UEFA Champions League. A total of 203 games of the teams "Atalanta» (Bergamo, Italy), "Atletico» (Madrid, Spain), «Bayern» (Munich, Germany), "Barcelona» (Barcelona, Spain), «Leipzig» (Leipzig, Germany), "Liverpool» (Liverpool, England), «Manchester City»(Manchester, England), "Olympique» (Lyon, France), "Paris Saint-Germain» (Paris, France) were registered and analyzed. The following research methods were used to solve the tasks: analysis of scientific and methodological literature, registration of technical and tactical actions, methods of mathematical statistics. Results: the article presents data characterizing the morphological features and features of the defensive and attacking TTA of the best players of different game specializations based on the results of the 2019/2020 UEFA Champions League games. Models of the best goalkeepers (Neuer M., Oblak J., Lopez A.), defenders (Davis A., Kimmich J., Alaba D., Upamekano D., Angelino, Van Dijk W.), midfielders (Thiago A., Goretzka L., Muller T., De Bruyne K., Auar W., Zabitzer M., Marquinhos, Gomez A.) and forwards (Gnabry S., Lewandowski R., Mbappe K., Neymar, Messi L., Sterling R.) were developed. Conclusions: the data of the study show differences in morphological parameters and the structure of the competitive activities of the best goalkeepers, defenders, midfielders and forwards in the games of the 2019/2020 UEFA Champions League.

Keywords: football players, model characteristics, age, height, weight, technical and tactical actions.

\section{References}

1. Golomazov, S., Chirva, B. (2000), «Modelnye kharakteristiki igry v shtrafnoi ploshchadi», Teoriia i praktika futbola, №2 (6), pp. 2-4. (in Russ.)

2. Golomazov, S., Chirva, B. (2003), «Morfologicheskie priznaki vratarei vysokoi kvalifikatcii», Teoriia i praktika futbola, №2 (18), pp. 25-28. (in Russ.)

3. Guba, V., Kuzmenko, lu., Stroeva, I., Chernova V. (2001), «Morfologicheskaia kharakteristika futbolistov 17-18 let», Teoriia i praktika futbola, №3 (11), pp. 17-19. (in Russ.)

4. Kostiukevych, V. M. (2006), «Modelni pokaznyky funktsionalnoi pidhotovlenosti futbolistiv», zbirnyk naukovykh prats z haluzi fizychnoi kultury i sportu, №10, p. 78. (in Ukr.)

5. Kostiukevich, V. M. (2006), Upravlenie trenirovochnym protcessom futbolistov v godichnom tcikle podgotovki, Vinnitca: Planer, 683 p. (in Ukr.)

6. Maksymenko, I. H., Kostiunin, A. V. (2007), «Analiz pokaznykiv zmahalnoi diialnosti futbolistiv zbirnoi komandy Ukrainy na chempionati svitu 2006", Slobozhanskyi naukovo-sportyvnyi visnyk, № 11, pp. 47-54. (in Ukr.)

7. Martirosov, E., Baluchi, R. (2006), «Morfologicheskie osobennosti futbolistov vysokoi kvalifikatcii raznykh amplua», Futbol-Profi, №2, pp. 60-65. (in Russ.)

8. Mulyk, V. V., Perevoznyk, V. I., Pertsukhov, A. A. (2015), «Kharakterystyka epizodiv hry v shtrafnomu maidanchyku komandy supernyka», Slobozhanskyi naukovo-sportyvnyi visnyk, №3 (47), pp. 75-79. (in Russ.)

9. Perevoznik, V. I., Pertcukhov, A. A. (2016), «Modelnye pokazateli podgotovlennosti futbolistov vysokoi kvalifikatcii», Problemy i perspektivy razvitiia sportivnykh igr i edinoborstv $v$ vysshikh uchebnykh zavedeniiakh, pp. 34-39. (in Russ.)

10. Perevoznik, V. I., Pertcukhov, A. A. (2017), «Modelnye pokazateli sorevnovatelnoi deiatelnosti futbolistov vysokoi kvalifikatcii», Problemy i perspektivy razvitiia sportivnykh igr i edinoborstv v vysshikh uchebnykh zavedeniiakh, pp. 41-45. (in Russ.)

11. Perevoznik, V. I., Pertcukhov, A. A. (2018), «Vozrastnye i antropometricheskie pokazateli futbolistov vysokoi kvalifikatcii», Slobozhanskii naukovo-sportivnii visnik, №6 (68). pp. 65-69. (in Russ.)

12. Perevoznik, V. I., Pertcukhov, A. A. (2018), «Funktcionalnaia podgotovlennost futbolistov vysokoi kvalifikatcii», Problemy i perspektivy razvitie sportivnykh igr i edinoborstv $v$ vysshikh uchebnykh zavedeniiakh, pp. 60-65. (in Russ.)

13. Pertcukhov, A. A. (2011), «Vzaimosviaz pokazatelei gabaritnykh razmerov tela i funktcionalnoi podgotovlennosti futbolistov $17-19$ let», Fizicheskoe vospitanie studentov, №4, pp. 64-66. (in Russ.)

14. Pertcukhov, A. A. (2017), «Osobennosti vypolneniia peredach miacha futbolistami komandy «Lester Siti» v igrakh chempionata Anglii 2015-2016 gg.», Slobozhanskii naukovo-sportivnii visnik, №3 (59), pp. 101-105. (in Russ.)

15. Pertcukhov, A. A. (2018), «Kharakteristika rezultativnykh udarov v vorota v igrakh komand vysokoi kvalifikatcii», Sportivnye igry, №2 (8), pp. 54-60. (in Russ.)

16. Pertcukhov, A. A., Perevoznik, V. I. (2019), «Dvigatelnaia aktivnost futbolistov vysokoi kvalifikatcii v usloviiakh sorevnovatelnoi deiatelnosti», Sportivnye igry, №1 (11), pp. 32-39. (in Russ.)

17. Platonov, V .N. (2004), Sistema podgotovki sportsmenov v olimpiiskom sporte. Obshchaia teoriia i ee prakticheskoe prilozhenie, Kiev: Olimpiiskaia literatura, 808 p. (in Russ.)

18. Shalenko, V. V., Pertcukhov, A. A. (2016), «Antropometricheskie pokazateli futbolistov vysokoi kvalifikatcii», Problemy i perspektivy razvitiia sportivnykh igr i edinoborstv v vysshikh uchebnykh zavedeniiakh, pp. 53-56. (in Russ.)

19. Shamardin, V. N. (2002), Modelirovanie podgotovlennosti kvalifitcirovannykh futbolistov, Dnepropetrovsk: Porogi, 200 p. (in Russ.)

20. Bangsbo, J. (1993), «The physiology of soccer - with special reference to intense intermittent exercise», HO + Storm, 155 p. (in Eng.).

21. Bangsbo, J. (1994), «Energy demands in competitive soccer», J. Sports Sci, №12, S. 5-12. (in Eng.).

22. Bangsbo, J. (1998), «The physiological profile of soccer players», Sports Exercise and Injury, №4, P. 144-150. (in Eng.).

23. Bangsbo, J., Norregaard, L., Thorsoe, F. (1991), «Activity profile of competition soccer», J. Sports Sci, №16 (2), P. 6 -110. (in Eng.).

24. Brewel, J., Davis, J.A. (1992), «A physiological comparison of English professional and semi-professional soccer players», J. Sports Sci, №10, P. 7-146. (in Eng.).

25. Broad, E. M., Burke, L. M., Cox, G. R., Heeley, P, Riley, M. (1996), «Body weight changes and voluntary fluid intakes during training and competition sessions in team sport», Int J Sport Nutr, №6 (3), P. 20-307. (in Eng.).

26. Casajus, J. A. (2001), «Seasonal variation in fitness variables in professional soccer players», J. Sports Med. Phys. Fitness, №41 (4), P. 9-463. (in Eng.).

27. Davies, J. A., Brewer, J., Atkin, D. (1992), «Preseasonal physiological characteristics of English first and second division soccer players», Journal of Sports Sciences, №10, P. 541-547. (in Eng.). 
28. Dupont, G., Akakpo, K., Berthoin, S. (2004), «The effect of in-season, high-intensity interval training in soccer players», J Strength Cond Res, №18 (3), P. 9-584. (in Eng.).

29. Pertsukhov, A., Perevoznick, V., Shalenko, V., Zhurid, S., Khudyakova, V., Koval, S. (2018), «Functional preparedness of football players with different qualifications", The Journal of Physical Education and Sport is now a registered trademark (all rights reserved), №104, PP. 710-714. (in Eng.).

30. Heller, J., Prochazka, L., Bunc, V. (1992), «Functional capacity in top league football players during the competitive season», J. Sports Sci, №10, 150 p. (in Eng.).

Received: 22.01.2021.

Published: 22.02.2021.

\section{Відомості про авторів / Information about the Authors}

Перцухов Андрій Анатолійович: к. фіз.вих; Харківська державна академія фізичної культури: вул. Клочківська, 99, м. Харків, 61058, Україна.

Перцухов Андрей Анатольевич: к. физ.восп; Харьковская государственная академия физической культуры: ул. Клочковская 99, г. Харьков, 61058, Украина.

Andrey Pertsukhov: PhD (Physical Education and Sport); Kharkiv State Academy of Physical Culture: Klochkivska 99, Kharkiv, 61058, Ukraine.

ORCID.ORG/0000-0003-1525-8488

E-mail: pertsukhov_82@ukr.net

Шаленко Віктор Васильович: к.фіз.вих., доцент; Харківська державна академія фізичної культури: вул. Клочківська, 99, м. Харків, 61058, Україна.

Шаленко Виктор Васильевич: к.физ.восп., доцент; Харьковская государственная академия физической культуры: ул. Клочковская, 99, г.Харьков, 61058, Украина.

Victor Shalenko: PhD (Physical Education and Sport), Associate Professor; Kharkiv State Academy of Physical Culture: Klochkivska 99, Kharkiv, 61058, Ukraine.

ORCID.ORG/0000-0002-3318-4956

E-mail: viktorshalenko.12@gmail.com 